\title{
G. Gajowiec
}

Politechnika Gdańska, Wydział Mechaniczny, Katedra Inżynierii Materiałowej, Gdańsk, Polska

\section{OCENA WPLYWU PARAMETRÓW NADTAPIANIA LASEROWEGO W WARUNKACH KRIOGENICZNYCH NA STRUKTURĘ WARSTWY WIERZCHNIEJ NA STOPIE Ti-6Al-4V}

\begin{abstract}
STRESZCZENIE
W pracy zostały przedstawione efekty przetapiania laserowego $\mathrm{w}$ warunkach kriogenicznych stopu tytanu Ti-6Al-4V. W celu określenia wpływu obróbki laserowej wykonano analizę mikrostruktury (SEM), składu fazowego (XRD), oraz pomiary mikrotwardości uzyskanych warstw. Stwierdzono, że zmiany podstawowych parametrów przetapiania laserowego - mocy wiązki lasera i prędkości skanowania istotnie wpływają na grubość i mikrostrukturę otrzymanych warstw. W wyniku przetapiania laserowego nastapił znaczny wzrost mikrotwardości. Obserwacje mikroskopowe wykazały, że otrzymane warstwy mają budowę dendrytyczną. Analiza składu fazowego wykazała obecność tlenków i azotków tytanu w warstwie wierzchniej. Efektem ubocznym opisywanej tu metody obróbki powierzchniowej jest obecność siatki pęknięć na powierzchni.
\end{abstract}

Stowa kluczowe: tytan, Ti-6Al-4V, nadtapianie laserowe

\section{WSTĘP}

Tytan i jego stopy posiadają bardzo dobry zestaw własności użytkowych, wśród których do najważniejszych można zaliczyć dobre własności mechaniczne, niską gęstość i wysoką odporność korozyjną w wielu środowiskach agresywnych. Dzięki tym własnościom stopy tytanu znajduje coraz większe zastosowanie w wielu gałęziach przemysłu. Ponadto tytan charakteryzuje się wysoką biozgodnością, dzięki czemu znajduje coraz szersze zastosowanie w medycynie - obecnie jest podstawowym materiałem metalicznym na implanty długoterminowe (endoprotezy stawów, implanty dentystyczne, zastawki serca, itp.). Natomiast istotną wadą tytanu i jego stopów, która ogranicza możliwości zastosowania go $\mathrm{w}$ wielu gałęziach przemysłu ( $\mathrm{w}$ tym $\mathrm{w}$ medycynie), są niskie własności trybologiczne - wysoki współczynnik tarcia oraz niska odporność na zużycie ścierne. Obserwacje kliniczne wykazały, że gdy implanty wykonane ze stopów tytanu narażone są na obciążenia trące, następuje niszczenie ścierne warstwy pasywnej, co powoduje w środowisku tkanek i płynów ustrojowych korozję, tribokorozję, zmęczenie korozyjne, a także nasilenie zjawiska metalozy [1-4].

Niskie własności trybologiczne modyfikowane są poprzez różnego rodzaju obróbki powierzchniowe, np. obróbkę cieplno-chemiczną, techniki PVD i CVD, napylanie plazmowe warstw odpornych na ścieranie, itp. Techniki wykorzystujące 
zjawisko dyfuzji na ogół wymagają nagrzania obrabianego materiału do wysokiej temperatury i długiego czasu wygrzewania, co może doprowadzić do rozrostu ziaren, a $\mathrm{w}$ rezultacie pogorszenia własności plastycznych i wytrzymałości zmęczeniowej. Natomiast warstwy wierzchnie otrzymywane w wyniku różnych technik opartych na osadzaniu tych warstw na powierzchni obrabianego przedmiotu mogą charakteryzować się niedostateczną adhezją do materiału podłoża. Dlatego ciaggle prowadzone są badania mające na celu opracowanie efektywnej technologii trwałych warstw przeciwciernych na stopach tytanu [5-15]. Jedną $\mathrm{z}$ metod, mogącą istotnie wpłynąc na poprawę własności trybologicznych, jest opracowana na Politechnice Gdańskiej technika przetapiania laserowego metali w warunkach kriogenicznych.

\section{MATERIAŁ I METODY BADAŃ}

Materiałem użytym do badań procesu nadtapiania laserowego stopów tytanu w warunkach kriogenicznych był dwufazowy, martenzytyczny stop tytanu Ti-6Al-4V. Próbki do badań zostały wycięte z blachy o grubości $12 \mathrm{~mm}$. Blacha dostarczona była $\mathrm{w}$ stanie walcowanym na gorąco, wyżarzona $\mathrm{w}$ temperaturze $750{ }^{\circ} \mathrm{C}$, pozbawiona zgorzeliny i wytrawiona. Skład chemiczny stopu oraz własności mechaniczne wg atestu hutniczego zostały zestawione w tabeli 1 i 2.

Tabela 1. Skład chemiczny dostarczonego do badań stopu tytanu Ti-6Al-4V

\begin{tabular}{|c|c|c|c|c|c|c|c|c|}
\hline Pierwiastek & $\mathrm{V}$ & $\mathrm{Al}$ & $\mathrm{Fe}$ & $\mathrm{C}$ & $\mathrm{O}$ & $\mathrm{N}$ & $\mathrm{H}$ & $\mathrm{Ti}$ \\
\hline \% masy & 4,08 & 6,39 & 0,17 & 0,015 & 0,185 & 0,005 & 0,0035 & Reszta \\
\hline
\end{tabular}

Tabela 2. Własności mechaniczne dostarczonego do badań stopu tytanu Ti-6Al-4V

\begin{tabular}{|c|c|c|}
\hline $\mathrm{R}_{0,2}[\mathrm{MPa}]$ & $\mathrm{R}_{\mathrm{m}}[\mathrm{MPa}]$ & $\mathrm{A}_{5}[\%]$ \\
\hline 1010 & 1072 & 13 \\
\hline
\end{tabular}

Proces nadtapiania próbek ze stopu tytanu Ti-6Al-4V został przeprowadzony na pomocą lasera molekularnego $\mathrm{CO}_{2}$ TRUMPF TLF 6000 TURBO, o długości fali 10,6 $\mu \mathrm{m}$, pracującego $\mathrm{w}$ trybie ciagłym. Przed procesem przetapiania powierzchnie próbek zostały pokryte substancją zaczerniającą w celu zwiększenia adsorpcji promieniowania laserowego, a następnie zanurzone w środowisku ciekłego azotu. Podczas eksperymentu została zastosowana wiązka prostokątna 1x20 mm, przy odległości głowicy lasera od powierzchni próbki około $10 \mathrm{~mm}$. Parametry nadtapiania laserowego zostały zestawione w tabeli 3.

Tabela 3. Parametry nadtapiania laserowego

\begin{tabular}{|c|c|c|c|c|c|c|c|c|c|c|c|c|}
\hline Nr próbki & 1 & 2 & 3 & 4 & 5 & 6 & 7 & 8 & 9 & 10 & 11 & 12 \\
\hline $\begin{array}{c}\text { Moc lasera } \\
{[\mathrm{kW}]}\end{array}$ & 2 & 2 & 2 & 3 & 3 & 3 & 4 & 4 & 4 & 5 & 5 & 5 \\
\hline $\begin{array}{c}\text { Prędkość } \\
\text { skanowania } \\
{[\mathrm{m} / \mathrm{min}]}\end{array}$ & 1 & 0,5 & 0,25 & 1 & 0,5 & 0,25 & 1 & 0,5 & 0,25 & 1 & 0,5 & 0,25 \\
\hline
\end{tabular}


Obserwacje mikroskopowe powierzchni próbek oraz analizę mikrostruktury warstw przetopionych zostały wykonane za pomoca skaningowego mikroskopu elektronowego PHILIPS XL-30 przy powiększeniach do 2000x. W celu ujawnienia mikrostruktury warstw przetopionych wykonano zgłady metalograficzne, które następnie trawiono odczynnikiem o składzie chemicznym: $6 \% \mathrm{HF}+2 \% \mathrm{HNO}_{3}+\mathrm{H}_{2} \mathrm{O}$. Skład fazowy powierzchni próbek określono metodą rentgenowską za pomoca dyfraktometru PHILIPS X'PERT z lampą miedzianą; długość fali promieniowania $\lambda_{\mathrm{K} \alpha 1}$ $=0,154056 \mathrm{~nm}, \lambda_{\mathrm{K} \alpha 2}=0,154439 \mathrm{~nm}$, stosunek $\lambda_{\mathrm{K} \alpha 1} / \lambda_{\mathrm{K} \alpha 2}=2$. Skład chemiczny warstw przetopionych określano metodą mikroanalizy rentgenowskiej za pomocą skaningowego mikroskopu elektronowego PHILIPS XL-30 wyposażonego w detektor EDX. Pomiary mikrotwardości zostały wykonane metodą Vickersa przy obciążeniu $0,49 \mathrm{~N}$.

\section{WYNIKI BADAŃ}

Na powierzchni próbek ze stopu Ti-6Al-4V, w wyniku przetapiania laserowego w atmosferze ciekłego azotu wytworzyły się warstwy o różnym zabarwieniu, w zależności od zastosowanych parametrów. Powierzchnie próbek przetapianych $\mathrm{z}$ większymi prędkościami i wiązkami lasera o mniejszej mocy mają barwę ciemnografitowa, z występującym lekkim, złotym opalizowaniem. Wraz ze wzrostem mocy wiązki lasera i spadkiem prędkości przetapiania powstające warstwy są coraz jaśniejsze i coraz wyraźniejsze staje się złote zabarwienie. Powierzchnie wszystkich próbek charakteryzują się widoczną nawet makroskopowo chropowatością - na powierzchni widoczne są cienkie, ciemne, gęsto rozmieszczone pasy biegnące prostopadle do kierunku ruchu wiązki lasera. Pomiędzy tymi pasami widoczne sa jasne obszary $\mathrm{z}$ występującym połyskiem metalicznym (szczególnie na próbkach przetapianych $\mathrm{z}$ większymi prędkościami i wiązkami lasera o mniejszej mocy), których obecność może świadczyć o dużych niejednorodnościach powstających warstw i braku przetopienia $\mathrm{w}$ tych obszarach. Dokładniejsze obserwacje stanu powierzchni przetapianych warstw wykonano przy pomocy skaningowego mikroskopu elektronowego. Wyniki tych badań zostały przedstawione na rysunkach 1-6.
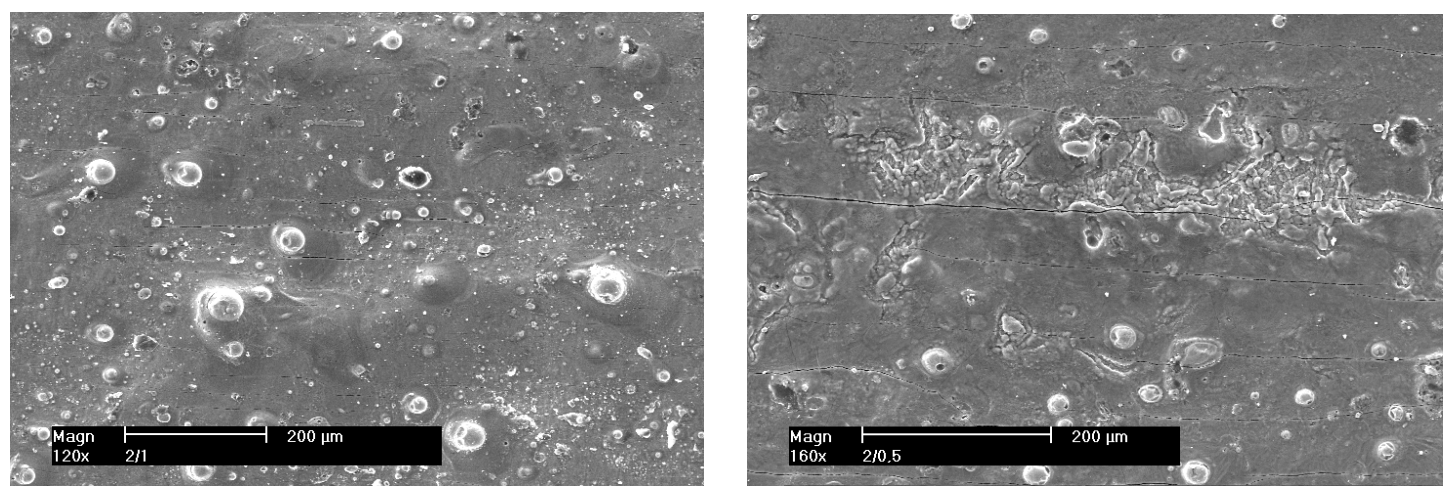

Rys. 1. Powierzchnia próbki nr 1 (po lewej) i nr 2 (po prawej) 

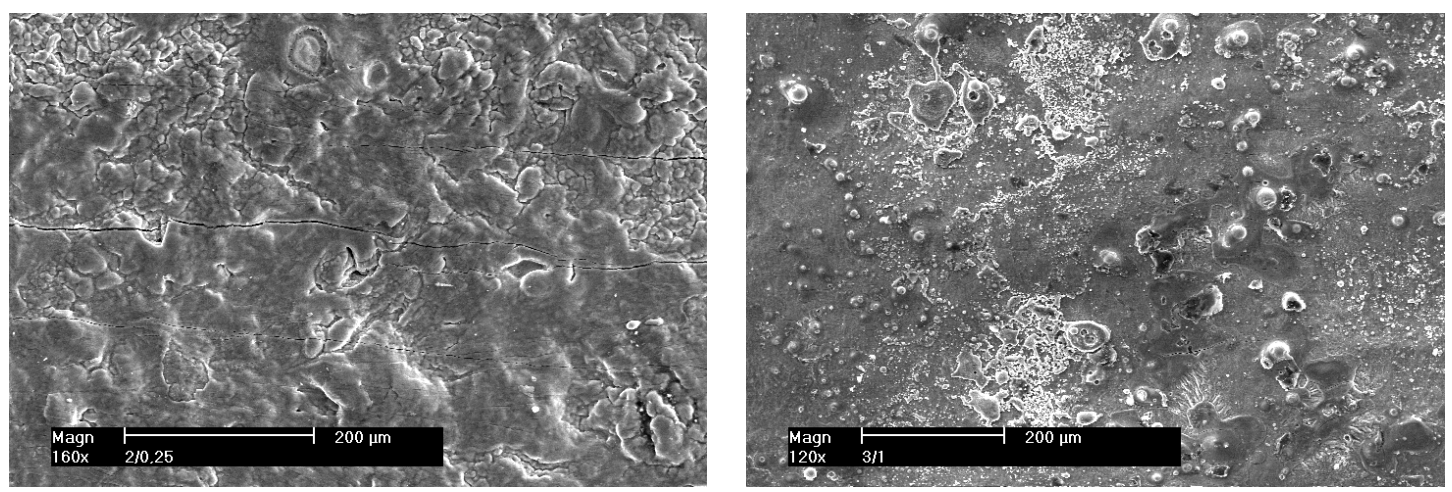

Rys. 2. Powierzchnia próbki nr 3 (po lewej) i nr 4 (po prawej)
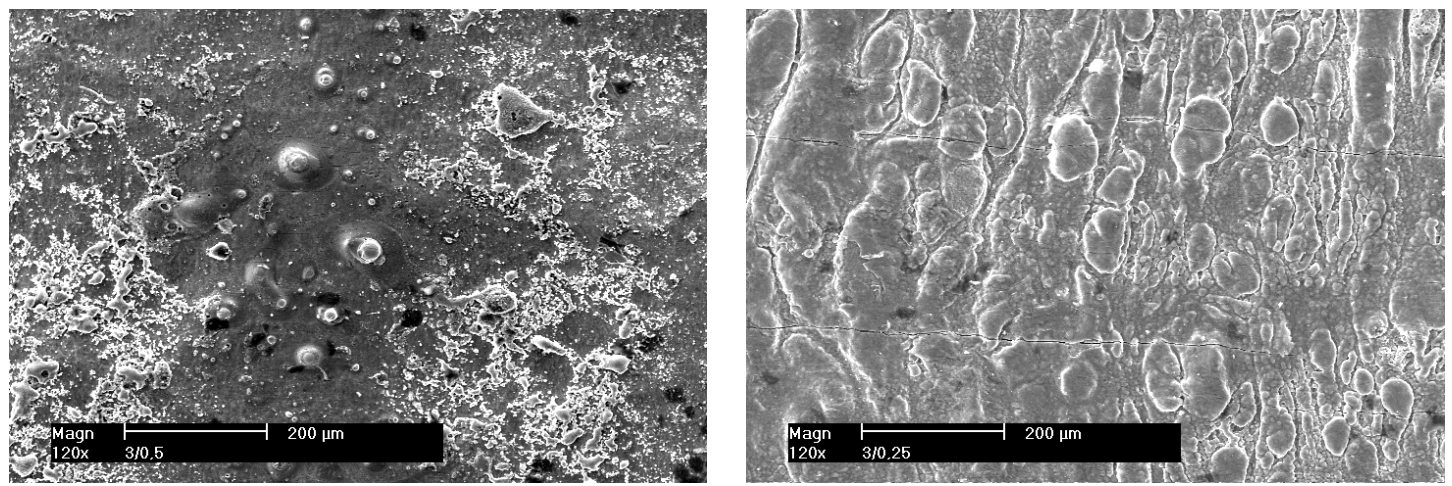

Rys. 3. Powierzchnia próbki nr 5 (po lewej) i nr 6 (po prawej)
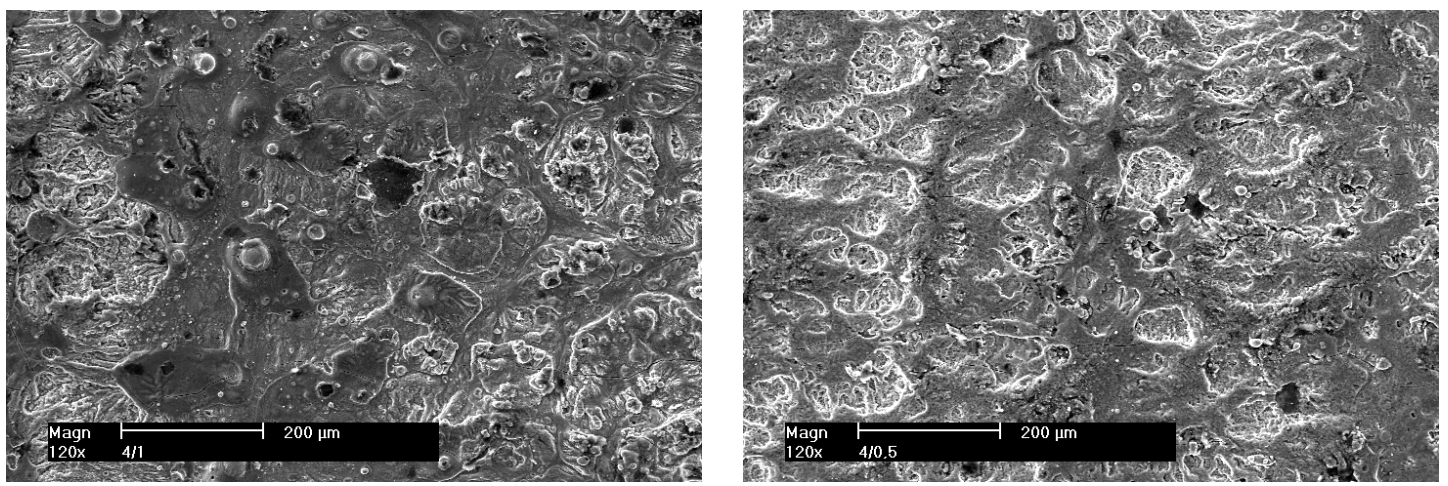

Rys. 4. Powierzchnia próbki nr 7 (po lewej) i nr 8 (po prawej)
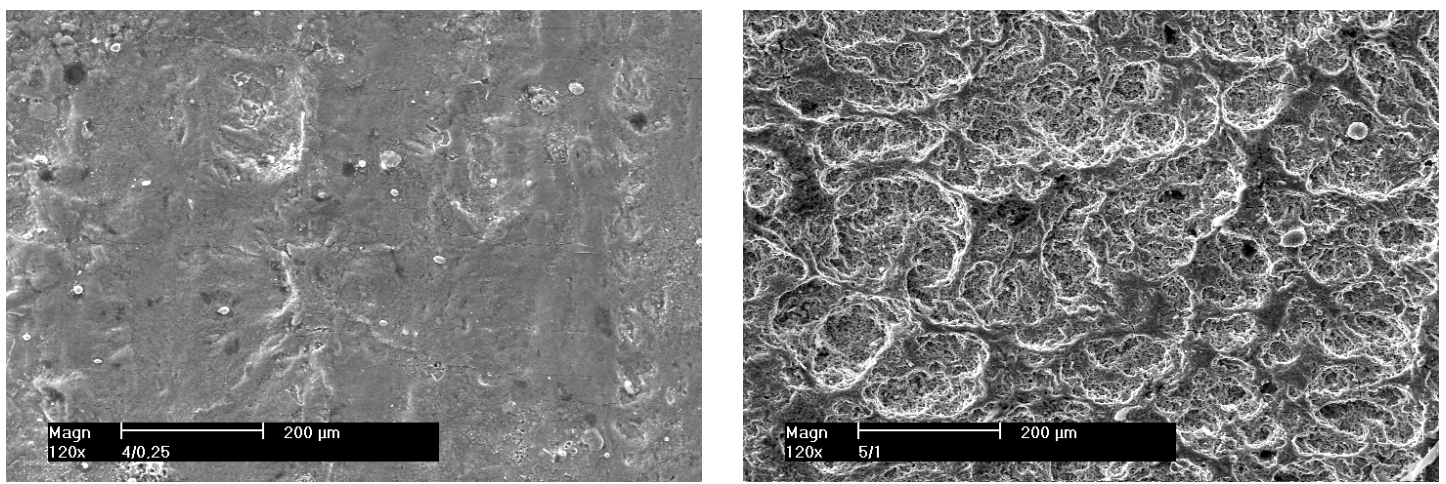

Rys. 5. Powierzchnia próbki nr 9 (po lewej) i nr 10 (po prawej) 

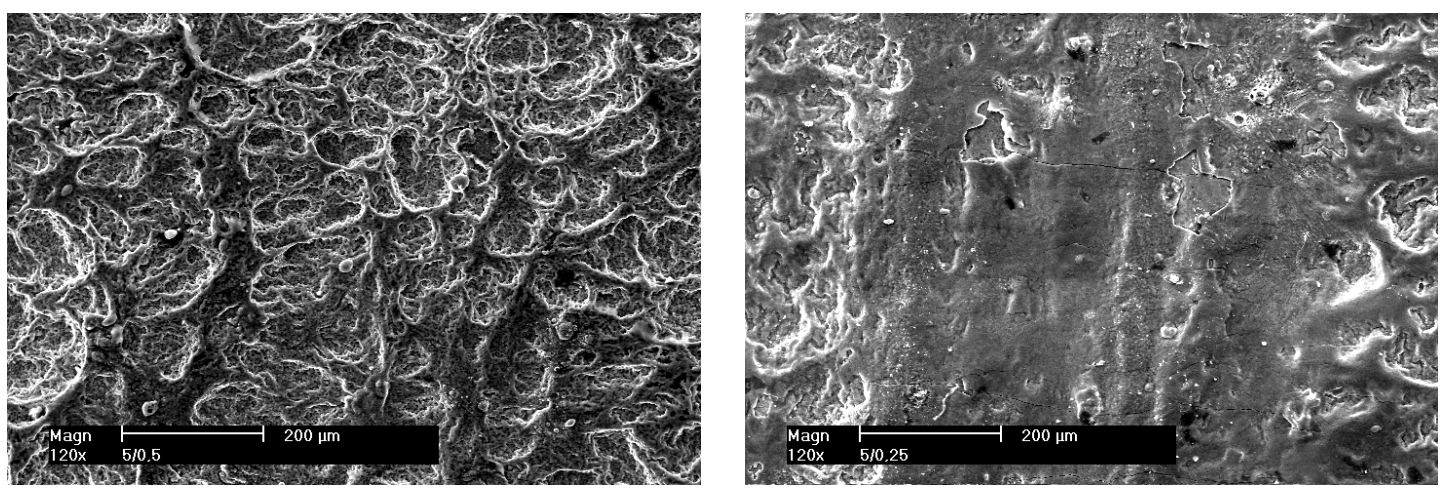

Rys. 6. Powierzchnia próbki nr 11 (po lewej) i nr 12 (po prawej)

$\mathrm{Na}$ powierzchni próbek przetapianych wiązką lasera o mniejszej mocy występują liczne wypukłe obszary o nieregularnym kształcie, a także twory przypominające wyglądem zakrzepnięte pęcherze i rozpryśnięte krople metalu. Wraz ze wzrostem mocy lasera na powierzchni pojawiają się coraz liczniejsze zagłębienia, na dnie których widoczne są kryształy o budowie dendrytycznej. Na powierzchni wszystkich próbek widoczne są pęknięcia przebiegające w większości w kierunku równoległym do kierunku ruchu wiązki lasera.

Badania składu fazowego próbek wykazały, że w wyniku przetapiania laserowego $\mathrm{w}$ atmosferze ciekłego azotu, na powierzchni przetapianych warstw wytworzyły się azotki tytanu $\mathrm{TiN}$ i $\mathrm{Ti}_{2} \mathrm{~N}$. Zaobserwowano również obecność tlenków tytanu $\mathrm{TiO}_{2}$ o strukturze rutylu $\mathrm{i}$ anatazu. Obecność tych tlenków świadczy o niedostatecznej „szczelności” ochronnej atmosfery ciekłego azotu. Wraz ze spadkiem mocy wiązki lasera i wzrostem prędkości przetapiania intensywność sygnałów pochodzących od tlenków i azotków maleje, co świadczy o zmniejszającym się ich udziale na powierzchni przetopionych warstw. W celu przeanalizowania wpływu parametrów przetapiania laserowego na mikrostrukturę warstw przetopionych wykonane zostały zgłady metalograficzne, które następnie były obserwowane przy pomocy skaningowego mikroskopu elektronowego. Wyniki tych badań dla wybranych próbek zostały przedstawione na rysunkach 7-12.
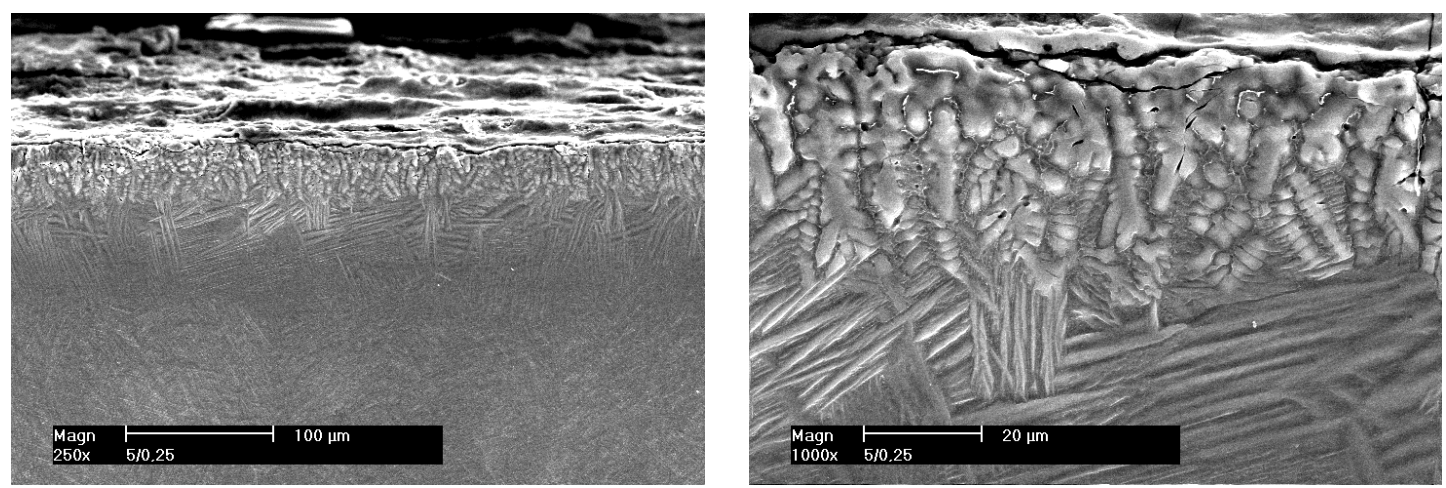

Rys. 7. Mikrostruktura próbki nr 12 

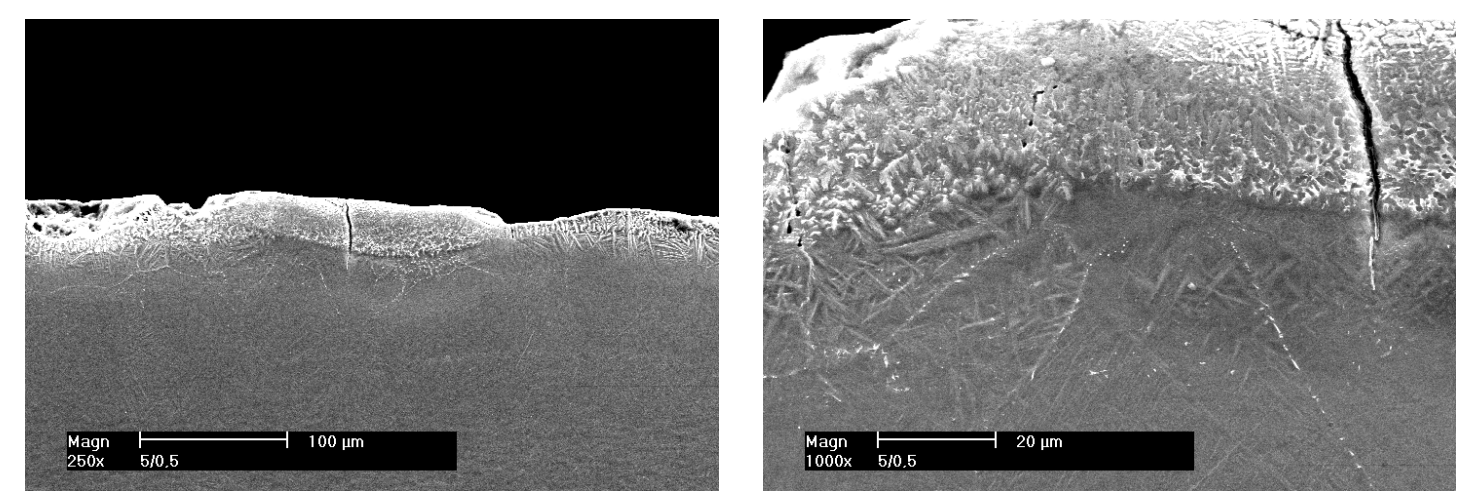

Rys. 8. Mikrostruktura próbki nr 11
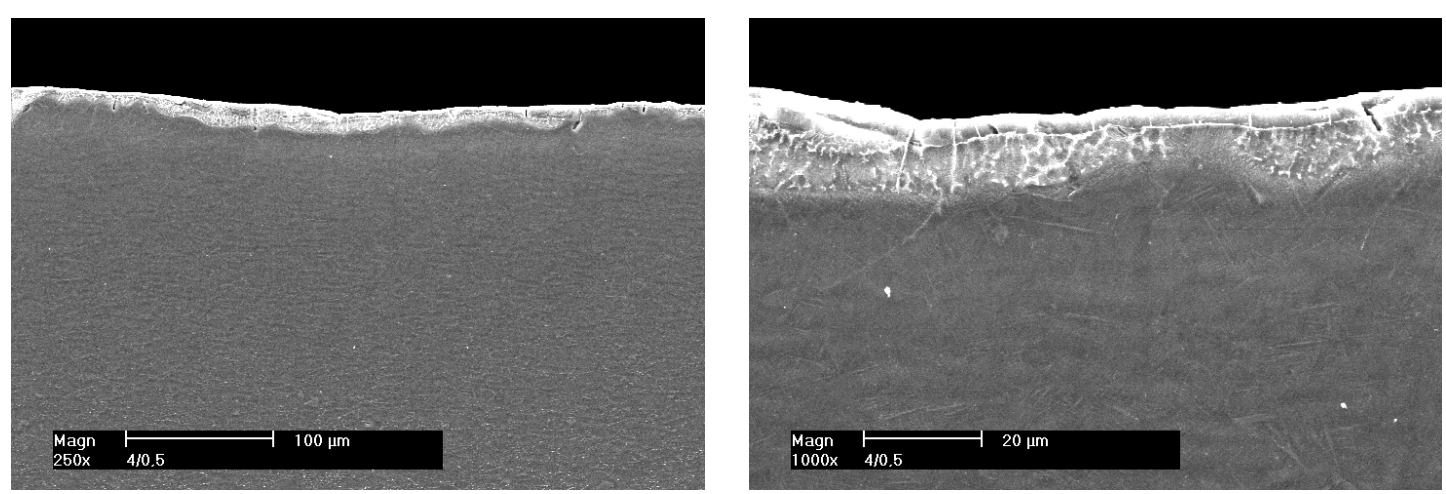

Rys. 9. Mikrostruktura próbki nr 8
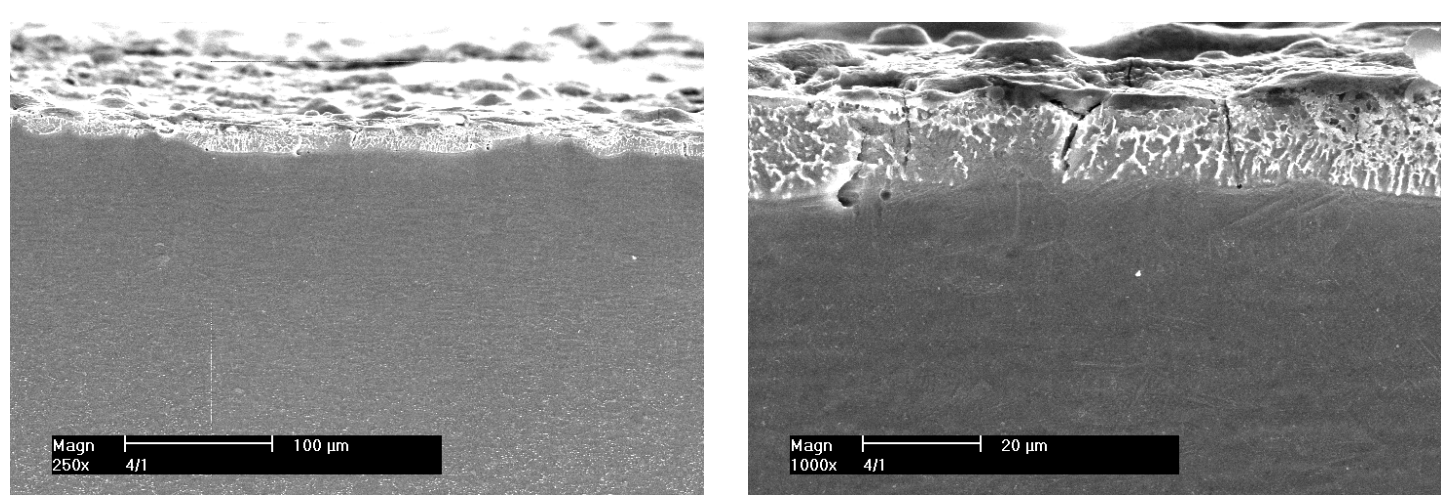

Rys. 10. Mikrostruktura próbki $\mathrm{nr} 7$
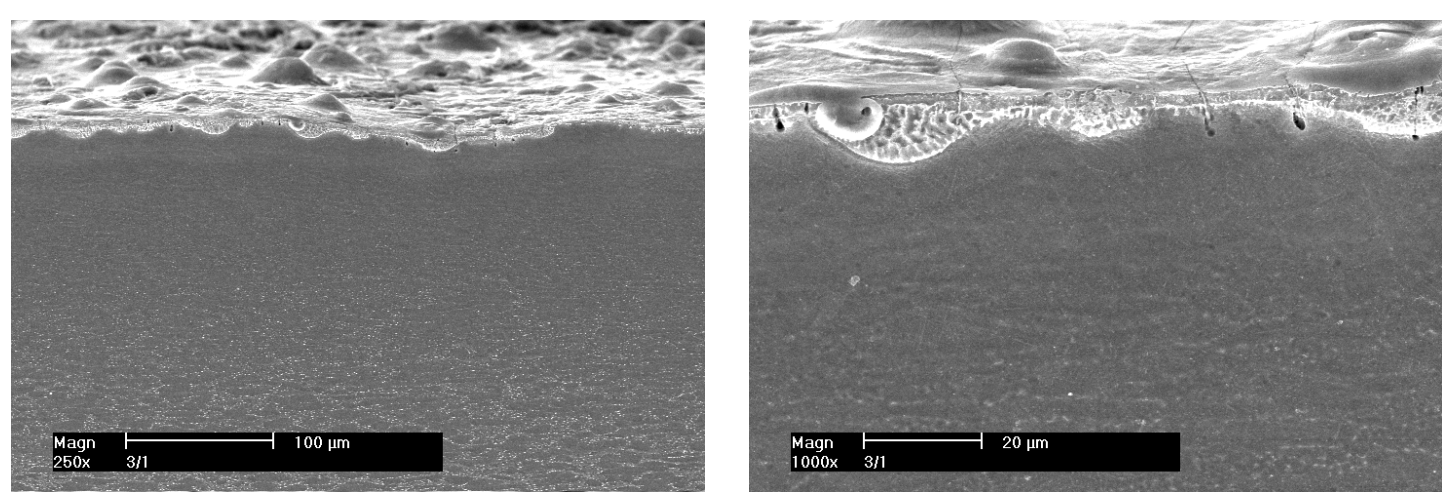

Rys. 11. Mikrostruktura próbki $\mathrm{nr} 4$ 

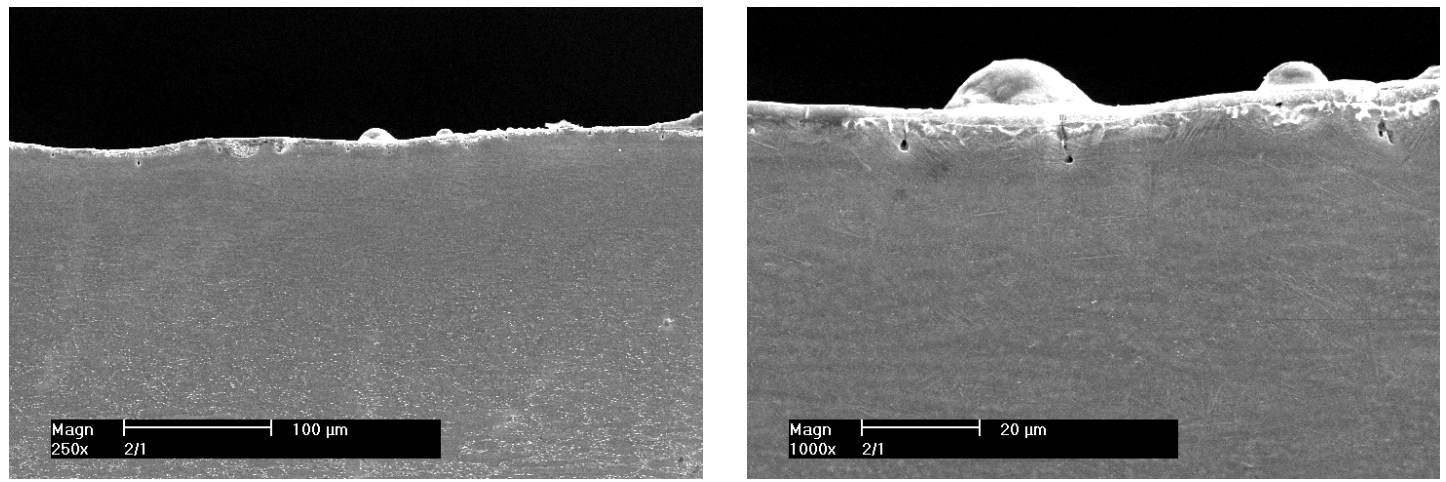

Rys. 12. Mikrostruktura próbki $\mathrm{nr} 1$

Warstwy uzyskane w wyniku przetapiania laserowego mają budowę strefową. Na powierzchni występuje cienka, ciagła warstwa, w której widoczne są przechodzące przez nią i wchodzące do głębszych stref pęknięcia. Poniżej występuje warstwa o budowie dendrytycznej (dendryty zbudowane z azotków i tlenków tytanu). Strefa ta ma budowę porowatą i występują w niej liczne pęknięcia. W warstwie tej zauważyć można również dendryty skierowane wierzchołkami w głąb próbki, których obecność świadczy o występowaniu zjawiska krystalizacji z dwoma frontami - jednym na granicy ciało stałe/ciecz na dnie strefy przetopienia, i drugim występującym przy warstwie wierzchniej stopionego metalu. Poniżej występuje strefa o budowie płytkowej, która przechodzi w strefę o budowie jednorodnej, która następnie w materiał rodzimy o charakterystycznej, dwufazowej strukturze $\alpha+\beta$. Zgodnie z przewidywaniami, wzrost mocy lasera i zmniejszenie prędkości skanowania próbki prowadzi do wzrostu grubości otrzymanych warstw, o coraz bardziej jednorodnych i rozbudowanych strefach.

Ponieważ jednym z najważniejszych parametrów wpływającym na odporność na zużycie w wyniku tarcia jest twardość materiału, zostały przeprowadzone badania mikrotwardości na przekroju poprzecznym. Badanie to zostało wykonane na próbce nr 12, ze względu na największą grubość uzyskanej warstwy oraz największą jednorodność budowy poszczególnych stref. Wyniki badań zostały przedstawione na rysunku nr 13.

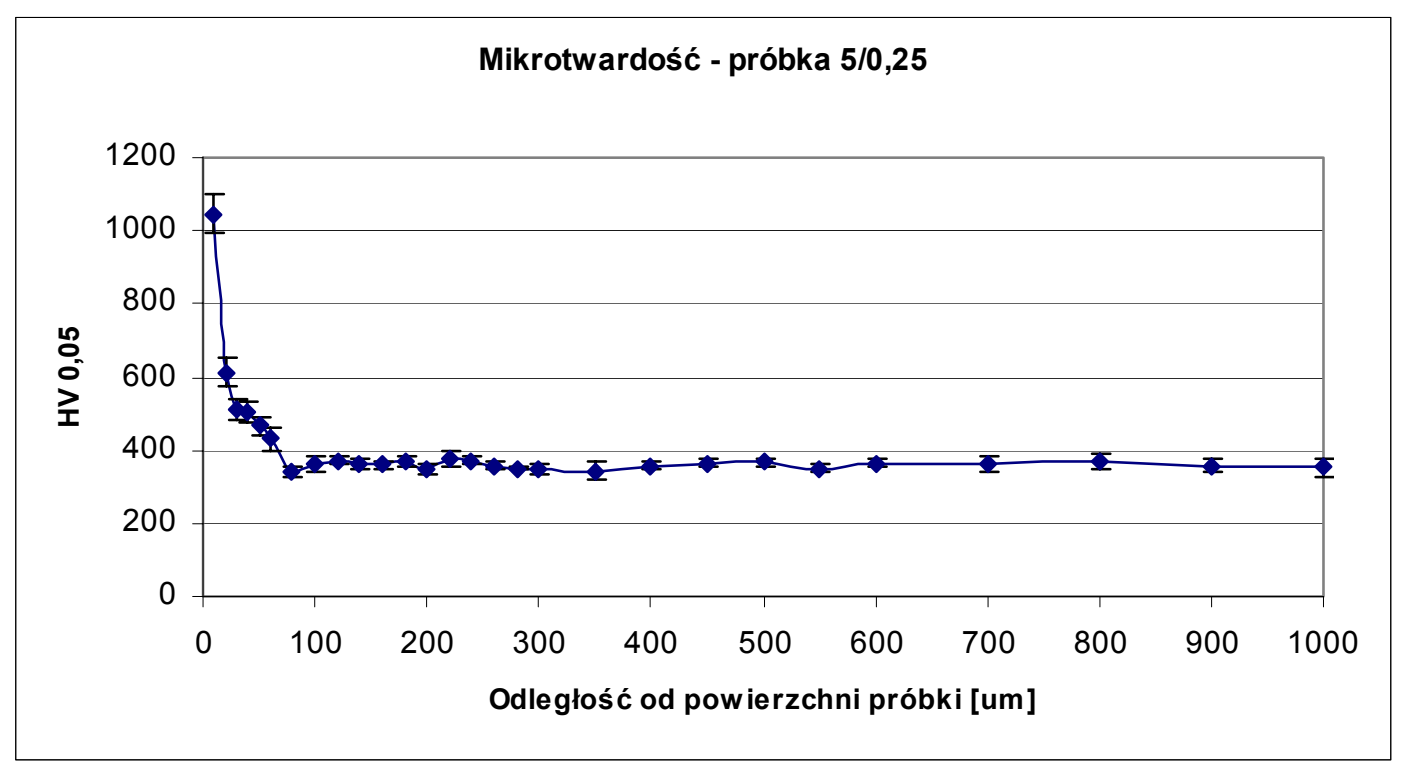

Rys. 13. Rozkład mikrotwardości w próbce $\mathrm{nr} 12$ 
Warstwa uzyskana w wyniku przetapiania laserowego charakteryzuje się dużą mikrotwardością - wynoszącą ok. 1045 HV0,05 na głębokości $10 \mu \mathrm{m}$ (nie udało się wykonać pomiarów w mniejszej odległości od powierzchni), jednakże wraz ze wzrostem odległości od powierzchni mikrotwardość szybko maleje i na głębokości 20 $\mu \mathrm{m}$ wynosi ok. $610 \mathrm{HV0,05}$. Na głębokości $60 \mu \mathrm{m}$ mikrotwardość wynosi ok. 430 HV0,05, poniżej waha się w granicach 340-370 HV0,05, i jest zbliżona do mikrotwardości stopu Ti-6Al-4V w stanie wyjściowym.

Badania przeprowadzone na próbkach ze stopu Ti-6Al-4V nadtapianych laserowo w atmosferze ciekłego azotu przy różnych parametrach (mocy wiązki lasera i prędkości skanowania próbki) wykazały znaczny wpływ zastosowanych parametrów na mikrostrukture przetopionej warstwy. Wraz ze wzrostem mocy wiązki lasera i obniżeniem prędkości skanowania próbki powstawały coraz grubsze warstwy o coraz bardziej jednorodnych i rozbudowanych strefach. Obserwacje mikroskopowe próbek wykazały, że większy wpływ na mikrostrukturę przetopionej warstwy mają zmiany prędkości skanowania niż zmiany mocy wiązki lasera. W wyniku nadtapiania laserowego rośnie mikrotwardość przetopionej strefy, co jest efektem powstawania twardych wydzieleń azotków i tlenków tytanu. Badania mikrostruktury i pomiary mikrotwardości wykazały gradientową - korzystną budowę przetopionej warstwy. Również sama strefa przypowierzchniowa charakteryzuje się korzystną mikrostrukturą - twarde wydzielenia azotków i tlenków tytanu rozmieszczone w ciągliwej, martenzytycznej osnowie. Do niekorzystnych efektów przetapiania laserowego należy zaliczyć występującą na wszystkich próbkach siatkę pęknięć oraz duże niejednorodności $\mathrm{w}$ budowie warstwy wierzchniej w kierunku równoległym do kierunku ruchu wiązki lasera. Obserwacje na skaningowym mikroskopie elektronowym wykazały, że pęknięcia we wszystkich próbkach przechodzą na wskroś przez warstwę dendrytyczna, która charakteryzuje się dużą twardością, dlatego konieczne jest prowadzenie dalszych badań $\mathrm{w}$ celu wyeliminowania lub zmniejszenia rozmiarów pęknięć.

\section{WNIOSKI}

1. Podstawowe parametry procesu nadtapiania - moc wiązki lasera i prędkość skanowania mają duży wpływ na mikrostrukturę i grubość przetopionych warstw. Wraz ze wzrostem mocy wiązki lasera i obniżeniem prędkości skanowania próbki powstają coraz grubsze warstwy o coraz bardziej jednorodnych i rozbudowanych strefach.

2. Nadtapianie laserowe próbek ze stopu tytanu Ti-6Al-4V w atmosferze ciekłego azotu prowadzi do znacznego wzrostu twardości, co jest związane $\mathrm{z}$ powstawaniem w przetopionej warstwie twardych wydzieleń tlenków i azotków tytanu.

3. Utworzona w wyniku przetapiania warstwa przypowierzchniowa charakteryzuje się korzystną mikrostrukturą - twarde, dendrytyczne wydzielenia azotków i tlenków tytanu rozmieszczone w ciągliwej, martenzytycznej osnowie.

4. Na powierzchni wszystkich próbek występują pęknięcia przechodzące na wskroś przez twardą warstwę dendrytyczną - konieczne są dalsze badania prowadzące do wyeliminowania tych pęknięć. 
5. Utworzone $\mathrm{w}$ wyniku przetapiania warstwy charakteryzują się dużymi niejednorodnościami w kierunku równoległym do kierunku ruchu wiązki lasera - konieczna jest modyfikacja parametrów nadtapiania prowadząca do wyeliminowania tych niejednorodności.

\section{LITERATURA}

1. Brunette D. M., Tengvall P., Textor M., Thomsem P.: Titanium in Medicine. Springer, Berlin 2001.

2. Marciniak J.: Biomateriały. Wydawnictwo Politechniki Śląskiej, Gliwice 2002.

3. Bylica A., Sieniawski J.: Tytan i jego stopy. PWN, Warszawa 1985.

4. Melechow R., Tubielewicz K., Błaszczuk W.: Tytan i jego stopy. Wydawnictwo Politechniki Częstochowskiej, Częstochowa 2004.

5. Filip R.: The effect of laser alloying on microstructure of Ti-6Al-4V titanium Alloy. Inżynieria Materiałowa 2004.

6. Filip R., Sieniawski J.: Mikrostruktura i właściwości użytkowe warstwy wierzchniej stopu tytanu Ti-6Al-4V kształtowanej metodą stopowania laserowego. Inżynieria Materiałowa 3/2006.

7. Filip R.: Kształtowanie mikrostruktury warstwy wierzchniej stopu tytanu Ti6Al-4V poprzez stopowanie laserowe. Inżynieria Materiałowa 5/2005.

8. Filip R., Sieniawski J.: Azotowanie stopu tytanu Ti-6Al-4V w warunkach przetopienia laserowego. Inżynieria Materiałowa 5/2005.

9. Major B.: Gradientowe warstwy uzyskiwane w procesach laserowych opartych o przetopienie oraz ablację. Materiały i Technologie 3/2005.

10. Filip R.: Wzbogacanie warstwy wierzchniej stopu tytanu Ti-6Al-4V węglem w warunkach przetopienia laserowego. VIII Ogólnopolska Konferencja - Tytan i jego stopy, Warszawa 2005.

11. Filip R., Sieniawski J.: Mikrostrukturalne efekty stopowania laserowego proszkiem Al i AlC w dwufazowym stopie tytanu Ti-6Al-4V. VIII Ogólnopolska Konferencja - Tytan i jego stopy, Warszawa 2005.

12. Zieliński A., Jażdżewska M., Narożniak-Łuksza A., Serbiński W.: Surface structure and properties of Ti6Al4V alloy laser melted at cryogenic conditions.

13. Jażdżewska M., Serbiński W., Zieliński A., Narożniak-Łuksza A.: Wpływ nadtapiania laserowego $\mathrm{w}$ warunkach kriogenicznych na strukturę warstwy wierzchniej stopu Ti-6Al-4V. Materiały i technologie 2006.

14. I. Garcia, J. J. de Damborenea: Corrosion properties of TiN prepared by laser gas alloying of Ti and Ti6Al4V. Corrosion Science Vol. 40, pp 1411-1419, 1998.

15. V. M. Weerasinghe, D. R. F. West, J. de Damborenea: Laser surface nitriding of titanium and a titanium alloy. Materials Processing Technology 1996. 